\title{
Ascorbic acid as a growth adjuvant in encapsulated protocorm-like bodies of Rhynchostylis retusa Bl. (Orchidaceae)
}

\author{
Jaspreet K. Sembi ${ }^{1}$, Parvinderdeep S. Kahlon ${ }^{2}$, Tania Kalsotra ${ }^{3}$, Sukhjeet K. Sidhu ${ }^{3^{*}}$ \\ ${ }^{1}$ Department of Botany, Panjab University, Chandigarh, India, ${ }^{2}$ Institute of Cellular and Molecular Botany, University of Bonn, Bonn, \\ Germany, ${ }^{3}$ Department of Biotechnology, SUS College of Engineering and Technology, Tangori, Mohali, Punjab, India
}

Received: 15.05 .2017

Accepted: 04.06.2017

Published: 08.06.2017

*Address for correspondence:

Sukhjeet K. Sidhu,

Department of

Biotechnology,

SUS College of Engineering

and Technology, Tangori,

Mohali, Punjab, India.

E-mail: sukhjeetsidhu.

biotech@gmail.com

\begin{abstract}
In the present study, effect of ascorbic acid, a known growth adjuvant on encapsulated protocorm-like bodies (PLBs) of Rhynchostylis retusa Bl. was investigated. PLBs were encapsulated in calcium alginate (3.5\% sodium alginate and $100 \mathrm{mM}$ calcium chloride) prepared in Mitra et al. (1976) basal medium and supplemented with different concentration of ascorbic acid $(5,10,15$ and $20 \mathrm{mM})$. The encapsulated PLBs were stored at $25^{\circ} \mathrm{C}$. Their germination response and germination potential were evaluated after every 4 weeks on basal media. Control set of encapsulated PLBs, failed to germinate after 32 weeks. However, PLBs with $15 \mathrm{mM}$ ascorbic acid in the encapsulated matrix showed the best response; nearly $90 \%$ germinated even after 32 weeks of storage. The survival and germination frequency was directly proportional to the level of ascorbic acid in the alginate mix up to $15 \mathrm{mM}$ level but declined on further increase. Differentiation of PLBs into plantlet was better in synthetic seeds containing lower concentration of ascorbic acid $(5 \mathrm{mM})$ as compared to higher levels $(15,20 \mathrm{mM})$ whereas multiplication of secondary PLBs was more pronounced at higher levels. Chlorophyll content was inversely proportional to the level of ascorbic acid in the nutrient mix; lush-green PLBs were observed at low concentration of ascorbic acid $(5 \mathrm{mM})$. This study highlights the potential of ascorbic acid as an aid to growth and survival of encapsulated PLBs upon storage.
\end{abstract}

KEY WORDS: Ascorbic acid, encapsulated protocorm-like bodies, Orchidaceae, Rhynchostylis retusa

\section{INTRODUCTION}

Orchidaceae constitute one of the largest families of angiosperms. Orchids are most valued as cut flowers and potted plants (Britt, 2000). Orchids are also acclaimed for their medicinal properties since Vedic times because of their rich phytochemical constituents mainly alkaloids, flavonoids, and glycosides (Jalal et al., 2008). Rhynchostylis retusa $\mathrm{Bl}$., an epiphytic fox-tail orchid is well known for its ornamental value owing to its floriferous nature (Vij et al., 1984). It is also reported to help in the treatment of dysentery, tuberculosis, epilepsy, menstrual disorders, fever, gout, asthma, rheumatism, and malarial fever (Radhika and Murthy, 2013). Due to its immense importance, it has been indiscriminately collected from the wild. Anthropogenic pressures and deforestation have further pushed the species on the verge of being threatened (Yagya and Fischer, 2011). Hence, there is a growing need to conserve this species. Encapsulated seed production has proven to be a better approach than other conventional in vitro propagation methods as the seeds are easy to handle, store, and transport; however, with limitations of loss of viability upon long-term storage (Shawky, 2006). There are various reports highlighting the use of encapsulated seed production for propagation and conservation of threatened orchids (Pradhan et al., 2014; Gantait and Sinniah, 2013; Mohanty et al., 2013; Siew et al., 2014).

It has been reported that addition of growth adjuvants can substantially increase the efficiency of synthetic seeds upon long-term storage. A well-established role of ascorbic acid as an antioxidant (Stasolla and Yeung, 1999) and enzyme cofactor (Foyer, 1993) has been reported in plants. Ascorbic acid acts as primary substrate for detoxifying hydrogen peroxide and neutralizes superoxide radicals and single oxygen. It also acts as a secondary antioxidant 
for reductive recycling of $\alpha$-tocopherol, a lipophilic antioxidant molecule (Noctor and Foyer, 1998). Hence, the present study was undertaken to investigate the role of ascorbic acid in conversion and growth of encapsulated protocorm-like bodies (PLBs) of R. retusa $\mathrm{Bl}$.

\section{MATERIALS AND METHODS}

\section{Plant Material}

A commercially important orchid species, namely, R. retusa $\mathrm{Bl}$. was selected for the present study. Green capsules (24WAP) were collected from naturally growing populations on Mangifera indica trees in Dehradun area (Uttaranchal, India). These were cultured asymbiotically following Kumar et al. (2002) to ensure regular supply of plant material. Synchronous PLBs to be used for encapsulation were obtained by clonal propagation using juvenile leaf explants (Vij et al., 1984).

\section{Encapsulation}

Encapsulated PLBs were prepared by the complexation between sodium alginate $(3.5 \mathrm{~g} / \mathrm{L})$ and calcium chloride $(100 \mathrm{mM})$. The propagules were dispersed in sterile (autoclaved at $1.1 \mathrm{~kg} / \mathrm{cm}^{2}, 121^{\circ} \mathrm{C}$ for $15 \mathrm{~min}$ ) sodium alginate matrix prepared in Mitra et al. (1976; M) medium supplemented with different concentrations of filter sterilized ascorbic acid. The suspension was then added drop wise (each drop containing a propagule) to stirred calcium chloride solution. The resultant beads were complexed for $30 \mathrm{~min}$ and washed thoroughly with sterile distilled water and stored at $25^{\circ} \mathrm{C}$.

\section{Data Recording and Analysis}

The germination potential was recorded periodically at 4 weeks interval up to 32 weeks by inoculating the encapsulated PLBs on fresh basal M medium. The data were collected in triplicate and represented as means (with 5\% error bar).

\section{RESULTS AND DISCUSSION}

Studies were carried out to evaluate the efficacy of ascorbic acid in enhancing growth and survival upon long-term storage in encapsulated PLBs of $R$. retusa. Ascorbic acid $(5,10,15,20 \mathrm{mM})$ was supplemented in encapsulated mix to check its potential as a growth adjuvant.

Ascorbic acid in different concentrations was added to the matrix before encapsulation of PLBs. The germination potential was evaluated at a 4 weeks interval. In the control set of experiments, the encapsulated PLBs failed to germinate after 32 weeks of storage at $25^{\circ} \mathrm{C}$. The presence of ascorbic acid in the encapsulation matrix; however, facilitated 60-90\% survival (Graph 1) after the same period. The survival percentage increased with increased level of ascorbic acid; up to $15 \mathrm{mM}$ which showed the best response (90\%) (Graph 1). This can be corroborated by a previous study by Sembi et al. (2014) in which $15 \mathrm{mM}$ of exogenous ascorbic acid-favored high germination response in encapsulated seeds.

Chlorophyll content in plantlets obtained from the encapsulated PLBs was inversely proportional to the level of ascorbic acid in the nutrient mix as evident from visual observations; lush-green leaves were observed in ascorbic acid ( $5 \mathrm{mM})$ and the chlorophyll content reduced with increase in ascorbic acid concentration (Figure 1a-c). Conversion of PLBs into plantlets was better in encapsulated PLBs containing lower concentration $(5,10 \mathrm{mM})$ of ascorbic

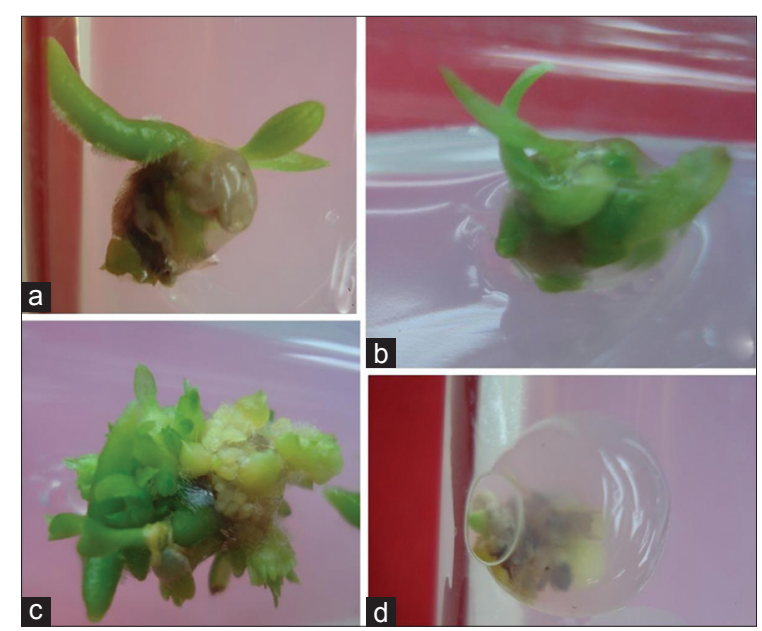

Figure 1: Morphogenetic response of encapsulated protocorm-like bodies (PLBs) of Rhynchostylis retusa under the effect of ascorbic acid $(5,10,15$, and $20 \mathrm{mM})$ : (a) Lush-green leaves with high chlorophyll content (5 mM); (b) PLBs conversion (10 mM); (c) excessive somatic embryogenesis and low chlorophyll content (15 mM); (d) growth inhibition (20 mM)

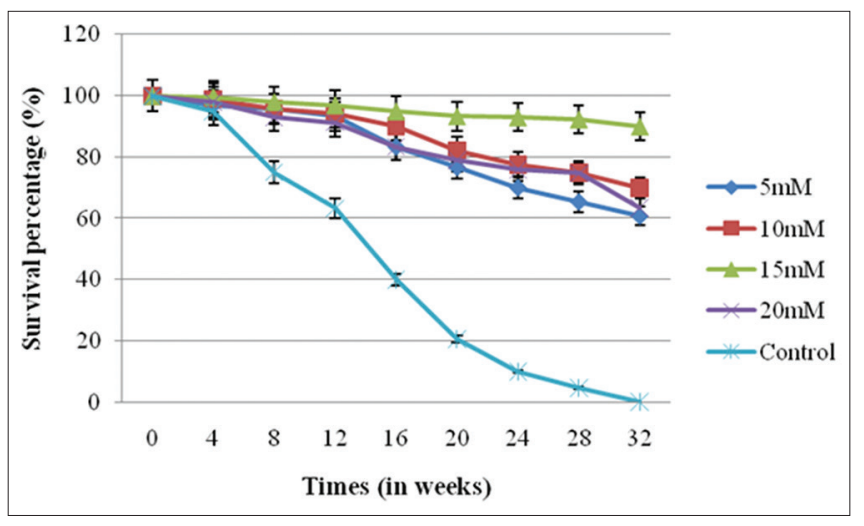

Graph 1: Survival percentage of encapsulated protocorm-like bodies in Rhynchostylis retusa under the effect of ascorbic acid $(5,10,15$, and $20 \mathrm{mM}$ ) up to 32 weeks 
Table 1: Different parameters observed of encapsulated PLBs in Rhynchostylis retusa under the effect of ascorbic acid $(5,10$, 15 , and $20 \mathrm{mM}$ )

\begin{tabular}{lccccc}
\hline Parameters & Control & $5 \mathrm{mM}$ & $10 \mathrm{mM}$ & $15 \mathrm{mM}$ & $20 \mathrm{mM}$ \\
\hline $\begin{array}{l}\text { Differentiation of PLBs into } \\
\text { plantlets }\end{array}$ & + & +++ & ++ & + & + \\
Somatic embryogenesis & + & - & + & +++ & + \\
Chlorophyll & + & +++ & ++ & + & + \\
Survival rate after 32 weeks & - & + & ++ & +++ & + \\
\hline
\end{tabular}

PLB: Protocorm-like bodies

acid (Figure 1a and b). Profuse somatic embryogenesis was observed at $15 \mathrm{mM}$ (Figure 1c) while higher concentrations (20 $\mathrm{mM}$ ) proved inhibitory (Figure 1d). Lower concentrations ( $5 \mathrm{mM}$ ) have been reported to be more suited for chlorophyll production and early differentiation of plantlets (Sembi et al., 2014). Beneficial effects of ascorbic acid in photosynthesis have been highlighted by Miyake and Asada (1992) and Smirnoff (1996).

Ascorbic acid plays major role in inhibition of oxidation process (Babbar et al., 2010) in addition it is showed by Ko et al. (2009) that it prevent browning of explants and increase the number of shoots. The use of activated charcoal and ascorbic acid in control of browning has also been reported by Abdelwahd et al. (2008), Nisyawati and Kariyana (2013), Zhou et al. (2010). In another study by Richard et al. (1988), enhanced organogenesis was reported in tobacco callus when ascorbic acid (0.4-0.8 mM) was added to the medium. Stasolla andYeung (2001) also reported enhanced conversion into plantlet of white spruce somatic embryos under the effect of exogenous ascorbic acid $(0.1 \mathrm{mM})$. Ascorbic acid at the concentration ( $0-30 \mathrm{mM}$ ) has been showed by Bybordi (2012) to play major role in inhibiting salt stress.

Our results and those of related studies suggest that ascorbic acid can effectively increase in germination potential, percentage growth, and differentiation on storage in encapsulated PLBs of R. retusa.

\section{CONCLUSIONS}

The present study highlights that exogenous ascorbic acid could play a pivotal role in improving germination, viability on storage, growth and differentiation of encapsulated PLBs and could serve as an aid to germplasm storage, multiplication, and conservation of R. retusa $\mathrm{Bl}$ as a growth adjuvant (Table 1 and Graph 1).

\section{ACKNOWLEDGMENTS}

The financial support by the Punjab State Council for Science and Technology, Chandigarh, India, is gratefully acknowledged.

\section{REFERENCES}

Abdelwahd RN, Hakam M, Labhilili M, Sripada MU. Use of an adsorbent and antioxidants to reduce the effects of leached phenolics in in vitro plantlet regeneration of faba bean. Afr J Biotechnol 2008;7:997-1002.

Babbar N, Oberoi HS, Uppal DS, Patil RT. Total phenolic content and antioxidant capacity of extracts obtained from six important fruit residues. Food Res Int 2011;44:391-6.

Britt J. The status of the commercial production of potted orchid around the world. Hortic Technol 2000;10:435-6.

Bybordi A. Effect of ascorbic acid and silicium on photosynthesis, antioxidant enzyme activity, and fatty acid contents in canola exposure to salt stress. J Integr Agric 2012;11:1610-20.

Foyer CH. Ascorbic acid. In: Alscher RG, Hess JL, editors. Antioxidants in Higher Plants. Boca Raton: CRC Press; 1993. p. 31-58.

Gantait S, Sinniah UR. Storability, post-storage conversion and genetic stability assessment of alginate-encapsulated shoot tips of monopodial orchid hybrid aranda wan chark kuan 'Blue' $\times$ Vanda coerulea Griff. Ex. Lindl. Plant Biotechnol Rep 2013;7:257-66.

Jalal JS, Kumar P, Pangtey YP. Ethnomedicinal orchids of Uttarakhand, Western Himalaya. Ethnobot Leaflets 2008;12:1227-30.

Ko WH, Su CC, Chen CL, Chao CP. Control of lethal browning of tissue culture planlets of Cavendish banana cv. Formosana with ascorbic acid. Plant Cell Tissue Organs Cult 2009;96:137-41.

Kumar A, Nandi SK, Bag N, Palni LM. Tissue culture studies in two important orchid taxa: Rhynchostylis retusa (L.) Bl. and Cymbidium elegans Lindl. In: Gyanodaya P, editor. Role of Plant Tissue Culture in Biodiversity Conservation and Economic Development. Nainital, India: Gyanodaya Prakashan; 2002. p. 113-24.

Mitra GC, Prasad RN, Chowdhary AR. Inorganic salts and differentiation of protocorms in seed callus of an orchid and correlated changes in its free amino acid content. Indian J Exp Biol 1976;14:350-1.

Miyake C, Asada K. Thylakoid-bound ascorbate peroxidase in spinach chloroplasts and photoreduction of its primary oxidation product, monodehydroaseorbate radicals in the thylakoids. Plant Cell Physiol 1992;33:541-53.

Mohanty P, Nongkling P, Das MC, Kumaria S, Tandon P. Short-term storage of alginate-encapsulated protocormlike bodies of Dendrobium nobile Lindl: An endangered medicinal orchid from North-East India. Biotechnology 2013;3:235-9.

Nisyawati, Kariyana K. Effect of ascorbic acid, activated charcoal and light duration on shoot regeneration of banana cultivar barangan (Musa acuminata L.) in vitro culture. Int J Res Res Appl Stud 2013;15:13-7. 
Noctor G, Foyer CH. Ascorbate and glutathione: Keeping active oxygen under control. Annu Revis Plant Physiol Plant Mol Biol 1998;49:249-79.

Pradhan S, Tiruwa B, Subedee BR, Pant B. In vitro germination and propagation of a threatened medicinal orchid, Cymbidium aloifolium (L.) SW. Through artificial seed. Asian Pac J Trop Biomed 2014;4:971-6.

Radhika B, Murthy N. Preliminary phytochemical analysis and in vitro bioactivity against clinical pathogens of medicinally important orchid of Rhynchostylis retusa $\mathrm{Bl}$. Am J Pharmtech Res 2013;3:510-20.

Richard W, Joy IV, Kamlesh RP, Trevor AT. Ascorbic acid enhancement of organogenesis in tobacco callus. Plant Cell Tissue Organs Cult 1988;13:219-28.

Sembi JK, Kahlon PK, Kalsotra T, Sidhu S. Effect of ascorbic acid, proline and mannitol on the desiccation tolerance of synthetic seeds in Rhynchostylis Retusa Bl. Am J Life Sci Res 2014;2:520-33.

Shawky AB. A synthetic seed method through encapsulation of in vitro proliferated bulblets of garlic (Allium sativum L.). Arab J Biotechnol 2006;9:415-26.

Siew WL, Kwok MY, Ong YM, Liew HP, Yew BK. Effective use of synthetic seed technology in the regeneration of dendrobiumm white fairy orchid. J Ornamental Plants 2014;4:1-7.

Smirnoff N. The function and metabolism of ascorbic acid in plant. Ann Bot 1996;78:661-9.

Stasolla C, Yeung EC. Ascorbic acid improves conversion of white spruce somatic embryo. InVitro Cell Dev Biol Plant 1999;35:316-9.

Stasolla C, Yeung EC. Ascorbic acid metabolism during white spruce somatic embryo maturation and germination. Physiol Plant 2003;111:196-205.

Vij SP, Sood A, Plaha KK. Propagation of Rhynchostylis retusa BL. (Orchidaceae) by direct organogenesis from leaf cultures. Bot Gaz 1984;145:210-4.

Yagya PA, Fischer A. Distribution pattern of the epiphytic orchid Rhynchostylis retusa under strong human influence in Kathmandu valley, Nepal. Bot Orient J Plant Sci 2011;8:90-9.

Zhou B, Xinfang W, Rongting W, Jingming J. Quantification of the enzymatic browning and secondary metabolites in the callus culture system of Nigella glandulifera freynet sint. Asian J Tradit Med 2010;5:109-16. 